\title{
A review of the main driving factors of forest fire ignition over Europe
}

\author{
Anne Ganteaume ${ }^{\mathrm{A}, \mathrm{C}}$, Andrea Camia ${ }^{\mathrm{B}}$, Marielle Jappiot ${ }^{\mathrm{A}}$, Jesus San-Miguel-Ayanz ${ }^{\mathrm{B}}$, Marlène \\ Long-Fournel $^{\mathrm{A}}$, Corinne Lampin ${ }^{\mathrm{A}}$
}

A : IRSTEA, UR EMAX, CS 40061, 13182 Aix-en-Provence, France

${ }^{B}$ : European Commission, Joint Research Centre (JRC), 21027, Ispra (VA), Italy

\author{
anne.ganteaume@irstea.fr \\ andrea.camia@jrc.ec.europa.eu \\ marielle.jappiot@irstea.fr \\ jesus.san-miguel@jrc.ec.europa.eu \\ marlene.long@irstea.fr \\ corinne.lampin@irstea.fr \\ ${ }^{\mathrm{C}}$ Corresponding author: Tel.: + 334426669 79, Fax : + 33442669923 \\ Email address: anne.ganteaume@irstea.fr
}

Additional key-words: ignition factors, fire occurrence, Mediterranean region

\begin{abstract}
Knowledge of the causes of forest fires, and of the main driving factors of ignition, is an indispensable step towards effective fire prevention policies. This paper analyses the factors driving forest fire ignition in the Mediterranean region including the most common human and environmental factors used for modelling in the European context. Fire ignition factors are compared to spatial and temporal variations of fire occurrence in the region, then are compared to results obtained in other areas of the world, with a special focus on North America (US and Canada) where a significant number of studies has been carried out on this topic.

The causes of forest fires are varied and their distribution differs among countries, but may also differ spatially and temporally within the same country. In Europe, and especially in the Mediterranean basin, fires are mostly human-caused mainly due arson. The distance to transport networks and the distance to urban or recreation areas are among the most frequently used human factors in modelling exercises and the WildlandUrban Interface is increasingly taken into account in the modelling of fire occurrence. Depending on the socioeconomic context of the region concerned, factors such as the unemployment rate or variables linked to agricultural activity can explain the ignition of intentional and unintentional fires. Regarding environmental factors, those related to weather, fuel and topography are the most significant drivers of ignition of forest fires, especially in Mediterranean-type regions. For both human and lightning-caused fires, there is a geographical gradient of fire ignition, mainly due to variations in climate and fuel composition but also to population density for instance. The timing of fires depends on their causes. In populated areas, the timing of human-caused fires is
\end{abstract}


Author produced version of the article published in Environmental Management, 2013, 51, 3, 651-662

Original publication available at www.springer.com

doi:10.1007/s00267-012-9961-z

closely linked to human activities and peaks in the afternoon whereas, in remote areas, the timing of lightningcaused fires is more linked to weather conditions and the season, with most such fires occurring in summer.

\section{Introduction}

Early in the Holocène, high climate seasonality favoured fire expansion in southern Europe, as it did in many other ecosystems of the northern and southern hemispheres. Later on, during the Neolitic Age, humans began affecting the fire regime that was previously related only to climatic conditions, leading to higher fire frequency (Vannière et al. 2008). Since then, fire plays a critical role in the structure and functioning of many ecosystems, especially in the Mediterranean basin but also in the other Mediterranean-type areas of the world (Naveh 1975; Gill et al. 1981; Keeley and Keeley 1988; Richardson and van Wilgen 1992). In these regions, human-caused fires are the most common (Keeley 1982; Kruger and Bigalke 1984; Vazquez and Moreno 1993; Fuentes et al. 1994) contrary to other regions such as the boreal forests, where lightning is often the major cause of ignition (Johnson, 1992). Despite its importance, knowledge of human causes of wildfires is still very limited (Lovreglio et al. 2006), although it is widely recognized that they can vary considerably.

In Europe, forest fires mostly affect Mediterranean regions where, on average, $85 \%$ of the annual burned area is recorded (San Miguel and Camia 2010). The main drivers of fire ignition are interconnected and evolve along parallel overarching trends to those of the human society and its use of forest resources. Socioeconomic developments in recent decades have led to changes in life patterns, with increasing mobility of people, spread of tourism and recreational activities and the resulting increase in the number of visitors to the forest. Additionally, in many rural areas of Mediterranean Europe, fire is a traditional and long established management tool. Its ancient and current use in agriculture, silviculture and livestock breeding is well documented (Bonora et al. 2002; Carmona-Moreno et al. 2005; Moreira et al. 2009). The traditional rural socioeconomic systems that once characterized the Mediterranean region collapsed in the last few decades, resulting in a rural exodus in the northern part of the Mediterranean basin (e.g., in Spain, Italy and Greece; Hill et al. 2008), and an overexploitation of natural resources in the eastern regions (e.g., Turkey, Lebanon and Cyprus). In parallel, huge, rapidly occurring land-use changes have taken place, including urbanization of coastal areas with the development of tourism and the construction of infrastructures, which have created conflicts and additional driving factors of forest fires. All the above-mentioned societal patterns have resulted in changes in fire ignition causes in the last decades.

The existence of a wide range of fire causes significantly complicates the assessment of fire risk since the factors that drive fire ignition have to be modelled, including human and environmental variables, as shown in several works (Bar Massada et al. 2009; Martínez et al. 2009; Thompson et al. 2011). Despite its importance, the influence of human factors on the spatial and temporal patterns of wildfire occurrence needs to be better understood (Sturtevand and Cleland 2007; Shlisky et al. 2007). As in Moreira et al. (2011) and Ricotta et al. (2012), fire risk is defined in this paper as "the chance of a fire starting as determined by the presence and activity of any causative agent” (FAO 1986; NWCG 2006), independently of how large the fire may become. Furthermore, fire hazard is defined as "a fuel complex, defined by volume type, condition, management and location, that determines the degree of ease of ignition and the resistance to control" (Hardy 2005; Moreira et al. 2011); fire hazard being thus connected to biomass availability. 
Author produced version of the article published in Environmental Management, 2013, 51, 3, 651-662

Original publication available at www.springer.com

doi:10.1007/s00267-012-9961-z

This paper aims at analysing the factors driving forest fire ignition, focusing on the European Mediterranean region. The study addresses the most common human and environmental factors of fire occurrence used for modelling in the European context. Fire ignition factors are compared to spatial and temporal variations of fire occurrence in the region. The analysis is mostly based on literature review, but it is also supported by results obtained processing data from the European Fire Database - EFD (Camia et al. 2010) of the European Forest Fire Information System (San-Miguel-Ayanz et al. 2012). Our results are then compared to those obtained in other areas of the world, with a special focus on North America (USA and Canada) and Australia where a significant number of studies has been carried out on this topic.

\section{Human factors}

Human agents are of great importance in fire risk assessment in Mediterranean countries where they are the main cause of forest fires either by accident/negligence or by deliberate action (arson) (Henderson et al. 2005). Analysis of data on fire causality in the EFD shows that, during the 2006-2010 period, the cause of forest fires in the Mediterranean countries was identified and recorded for $71 \%$ of the events. Of those fires with known cause, $55.8 \%$ were due to deliberate action, $33.5 \%$ to negligence, $6.1 \%$ to accident and $4.7 \%$ to natural causes. In Table 1 these figures are compared with those of northern and central Europe. In northern European countries, the relative frequency of deliberate fires is remarkably lower (13.9\%), while $78.8 \%$ of the fires are recorded as caused by accident or negligence; fires due to natural causes are also much higher in number (7.8\%). In central Europe, the share of deliberate fires is similar to that of the Mediterranean countries, while the incidence of natural causes is very low (0.5\%). Overall, when all regions are considered together, it is observed that $97.1 \%$ of fires in Europe are directly or indirectly caused by human agents.

Table 1 Relative frequency of fires by main fire causes in Europe in 2006-2010 (fires with known causes). Data elaborated from the European Fire Database (Europe North: Estonia, Finland, Latvia, Lithuania, Sweden; Europe Centre: Bulgaria, Germany, Hungary, Poland, Romania, Slovakia, Slovenia, Switzerland; Europe South (Mediterranean): France, Greece, Italy, Portugal, Spain)

\begin{tabular}{|lcrrrr|}
\hline & $\begin{array}{c}\text { Fires of known cause } \\
\text { (\% of total fires) }\end{array}$ & \multicolumn{4}{c|}{ Fire causes (\% of fires of known cause) } \\
\cline { 3 - 6 } Europe North & $\mathbf{8 0 \%}$ & Natural & Accident & Negligence & Deliberate \\
Europe Centre & $\mathbf{8 7 \%}$ & $\mathbf{7 . 3 \%}$ & $\mathbf{1 4 . 1 \%}$ & $\mathbf{6 4 . 7 \%}$ & $\mathbf{1 3 . 9 \%}$ \\
Europe South & $\mathbf{7 1 \%}$ & $\mathbf{4 . 7 \%}$ & $\mathbf{6 . 0 \%}$ & $\mathbf{3 3 . 5 \%}$ & $\mathbf{5 5 . 8 \%}$ \\
\hline
\end{tabular}

Early attempts to model human-caused fire occurrence were based on indirect assessments of human activity using demographic indicators or data on generic accessibility to forested areas (Cunningham and Martell 1976; Altobellis 1983; Donoghue and Main 1985). Later on, several spatial analyses of fire occurrence explored the role of spatially explicit factors such as distance to roads, location of recreational areas or distance to urban settlements (Chuvieco and Congalton 1989; Vega-García et al. 1995; Alexandrian 1995; Russell-Smith et al. 1997; Follin 1999; Cardille et al. 2001; Pew and Larsen 2001; Vasconcelos et al. 2001; Decarnin 2002; Prestemon and Butry 2005; Mollicone et al. 2006; Maingi and Henry 2007; Vasilakos et al. 2007; Yang et al. 2007). Indeed, the analysis of human-caused fire occurrence requires a comprehensive assessment, integrating in one framework spatially explicit variables related to human activities (e.g. location and distance to 
Author produced version of the article published in Environmental Management, 2013, 51, 3, 651-662

Original publication available at www.springer.com

doi:10.1007/s00267-012-9961-z

infrastructures such as roads, railways, power lines, populated areas or recreational sites, the configuration of wildland/urban interface areas) as well as socio-economic variables and indicators affecting human ignition (e.g. unemployment rates, age of rural populations, population density, housing density, etc.). Many authors have shown that a large number of fire ignitions can be explained by the first group of factors (Langhart et al. 1998; Mangiavillano 2004; Lampin et al. 2005 and 2006; Badia-Perpinya and Pallares-Barbera 2006; Catry et al. 2007; Romero-Calcerrada et al. 2008; Vasilakos et al. 2008; Martínez et al. 2009; Padilla and Vega-García 2011). On the other hand, socio-economic indicators such as the unemployment rate have also been shown to be clearly linked to fire occurrence in many areas of southern Europe (Ferreira de Almeida et al. 1992, Leone 1999, Chuvieco et al. 1999, Velez 2000, Sebastian-Lopez 2008). Catry et al. (2007) observed that more than $70 \%$ of the fire ignitions in Portugal occurred in the municipalities with the highest population densities (more than 100 inhabitants per $\mathrm{km}^{2}$ ), that $85 \%$ of the fires occurred close to urban areas (i.e. located at a distance of less than $500 \mathrm{~m}$ ) and that $70 \%$ occurred close to main roads (at a distance of less than $500 \mathrm{~m}$ ). Similarly, RomeroCalcerrada et al. (2008) suggested that, in Spain, the increasing presence of people near woodlands and socioeconomic trends may have been producing wildfire ignition patterns that increasingly resemble those in Mediterranean-type regions with historically stronger economies such as California. These authors found clear evidence for a positive relationship between the intensive use of the territory and the ignitions in forest areas, with a significantly higher occurrence of fires in the vicinity of urban areas and transport networks (at a distance of between 50 and $250 \mathrm{~m}$ from urban areas and less than $50 \mathrm{~m}$ from tracks). This trend was also underlined in the work of Padilla and Vega-García (2011). However, the spatial distribution of fires in relation to these factors may reveal different tendencies. According to Alexandrian and Gouiran (1990), in France, some fires occurred close to roads, around highly populated towns or in forest fragmented areas, whereas other fires were ignited near isolated dwellings in large forest stands. Other authors, such as Archibald et al. (2009), confirmed the positive relationship between population density and occurrence of fires; however they showed that, simultaneously, there was also a decrease in the total area burned with increasing human densities because of the decrease in mean and maximum fire size.

It has been hypothesised that the higher wildfire occurrence observed in recent years is linked to landscape homogenisation due to land use changes (Duguy 1998; Farina 1998). Land use and land cover changes that occurred in the last decades in Mediterranean Europe have been generally increasing fire hazard (Moreira et al. 2011). Indeed, the abandonment of rural areas implies an increase in shrubland and forest areas and a corresponding decrease in grassland and cultivated land. The colonisation of agricultural fields by natural vegetation tends to simplify the traditional landscape mosaic and at the same time increases fuel loads (RomeroCalcerrada and Perry 2004; Badia-Perpinya and Pallares-Barbera 2006; Vasilikos et al. 2008; Koutsias et al. 2012). However, it is questionable whether this process increases fire ignition probability rather than fire hazard. In fact, Catry et al. (2007) found that, in Portugal, most ignitions occurred in agricultural (60\%) and social/urban areas (25\%), while only $15 \%$ of the ignitions occurred in forested or uncultivated areas. Similar results were found in the European Mediterranean area by Santos de Oliveira et al. (2009). Ricotta et al. (2012) showed that, in a Mediterranean region of Italy, the decreased human pressure following agricultural land abandonment lowered fire ignition probability. In regions where the proportion of agricultural land remains high (for instance Spain, southern Italy or Slovakia), one of the main causes of fire is the negligent use of fire in agricultural practices like burning stubble (Tuček and Majlingova 2009; Lovreglio et al. 2010; Figure 1), which is also linked 
to the gradual loss of "fire culture" among the rural population (Lazaro and Montiel 2010). For this reason, factors such as the density of agricultural plots or the density of agricultural machinery were used for ignition modelling purposes in Spain (Martínez et al. 2009). The average age of farmers was also suggested to explain fire ignition in rural areas. The aging of rural population has increased the risk associated with traditional fire use practices, which have evolved to be at present among the main causes of unintentional fires in most Mediterranean countries (FAO 2007; JRC-IES 2008).

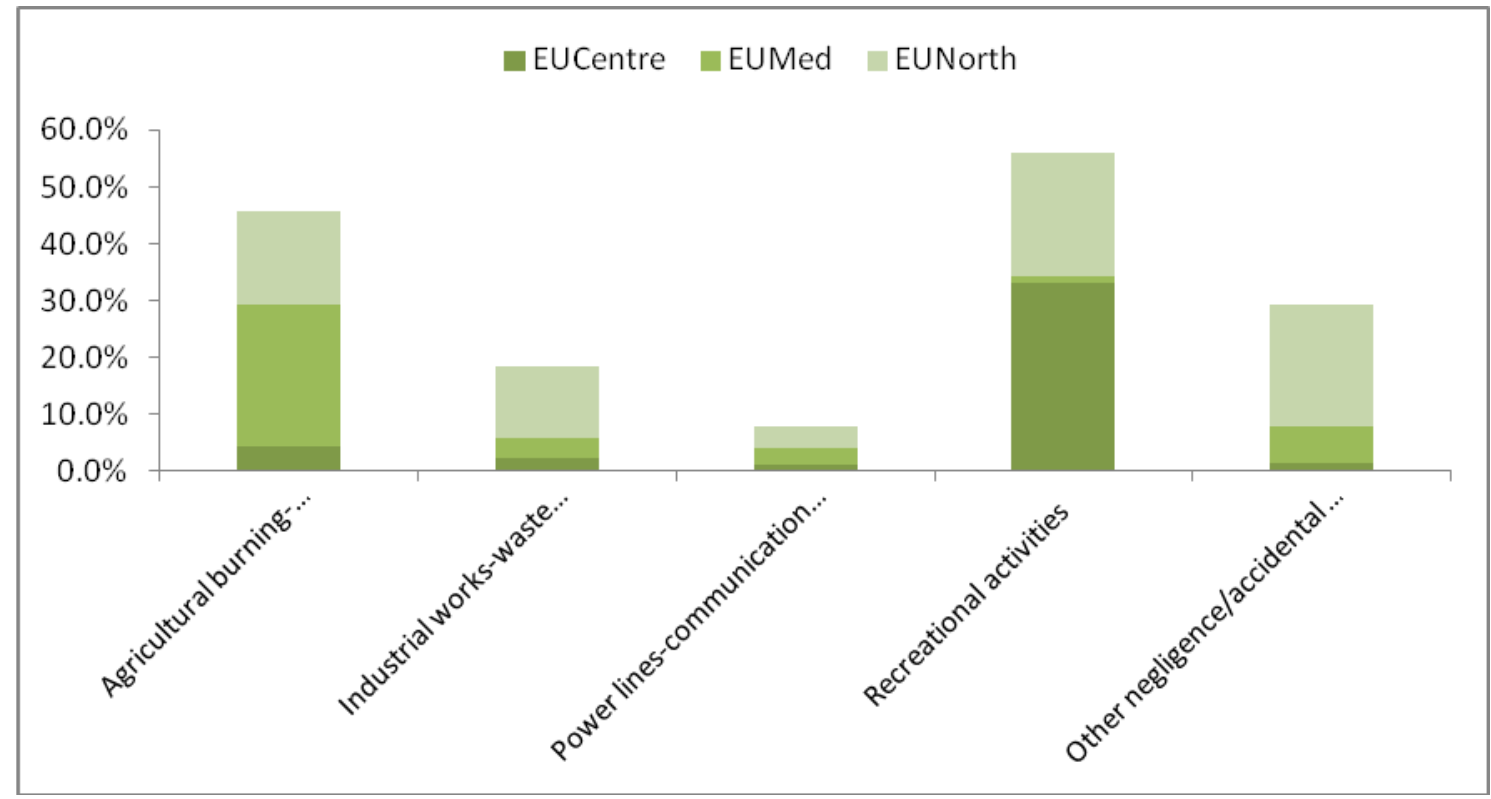

Fig. 1 Comparison of fire frequency by causes due to negligence/accident in northern, central and Mediterranean Europe (EFD 2006-2010)The footprint of socio-economic drivers on the change of fire ignition patterns can also be recognized in the trend of fire causes in Mediterranean Europe during the last 15 years. Results from the EFD (Figure 2) show that voluntary fires have decreased from 71\% in the period1995-1999 to $56 \%$ in the period 2006-2010; fires due to negligence have increased from $22 \%$ to $33 \%$, while accidental fires have increased from $3 \%$ to $6 \%$ of the events with known causes in the mentioned periods. Thus it appears that the overall effect of changes in the rural population and the parallel shift of main users of natural resources led to an increase of accidental and negligence caused fires.

Regarding intentional fires, high fire occurrence is linked to different motivations, which in turn depend on the socio-economic or political context of the region or country concerned. In southern Italy, for instance, Lovreglio et al. (2010) identified as major motivations of voluntary fires those linked to policies concerning seasonal forest workers; in this case fires were used as an instrument to force or maintain seasonal employment. In Galicia (NW Spain) and in northern Portugal, arson is also a major problem and has its roots in social conflicts. In some cases, the conflicts arose because government plantations were established on lands that were previously used as rangelands by the local community (Moreira et al. 2001, Tabara et al. 2003). In Greece, Lekakis (1995) concluded that political decisions and economic developments leading to increased demand for land were largely responsible for the reduction in the forested area in Greece due to fires.

At the global scale, human factors are proven to be related to fire persistency and seasonality, while fire density patterns are associated to human variables for specific climates and vegetation covers (Chuvieco and 
Justice 2010).The great influence of anthropogenic activities on global patterns of fire seasonality was also underlined by Le Page et al. (2010).

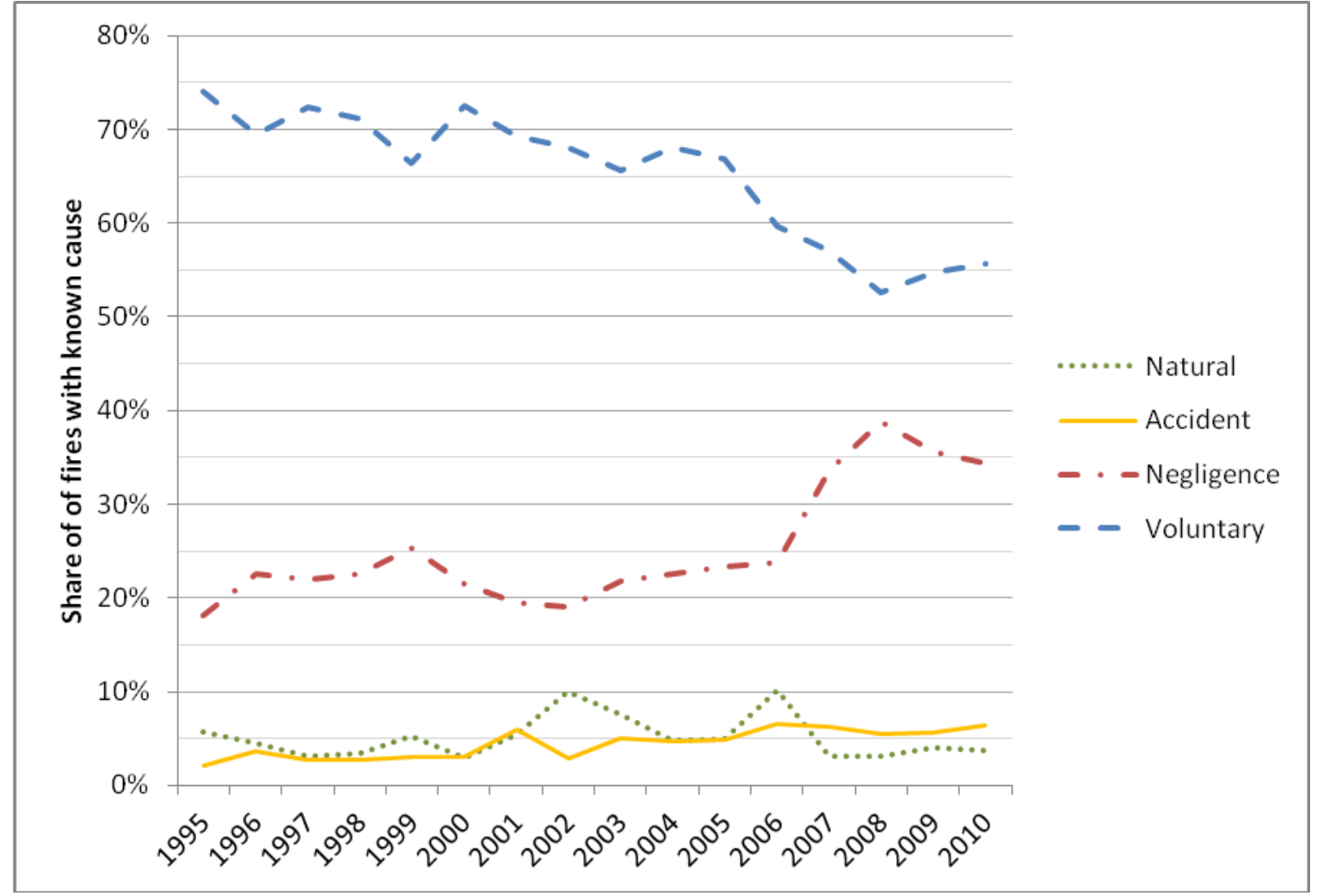

Fig. 2 Relative frequency of fires with known causes in the European Mediterranean countries from 1995 to 2010 (EFD)

\section{Environmental factors}

Despite the direct or indirect human origin of most forest fires, environmental factors affecting flammability of Mediterranean fuels have also been considered as predictors of fire occurrence. It is well established that the Mediterranean summer weather conditions (high temperature, prolonged drought periods and strong winds) play a significant role in the fire regimes in the region. Several attempts to link weather factors and fire occurrence in Europe include those of Vazquez and Moreno (1993) who linked fire occurrence with drought, and Vasilakos et al. (2008) who linked fire occurrence with rainfall and wind. Efforts to include fuel characteristics (e.g. Bossard et al. 2000; Sebastian-Lopez 2008; Chuvieco et al. 2010; Padilla and Vega-García 2011) or topographic factors (e.g. Vazquez and Moreno 2001, Vasilakos et al. 2008; Padilla and Vega-García 2011) in fire occurrence modelling are also documented. Furthermore, the synergistic effect of fuel and weather has been underlined during large and catastrophic fires such as those that occurred in Greece in 2007 (Koutsias et al. 2012).

Concerning the environmental factors that cause forest fires, the fire pattern in a region associated with natural ignition sources is traditionally referred to as a 'natural fire regime'. In this case, fires are ignited by lightning or by other natural sources (e.g. volcanic activity or gas emissions), though these other sources are rare and only occur in a few regions in the world. Lightning is the main natural cause of ignition all over the world (Komarek 1964) and in some areas where population density is very low, such as the American boreal forest, it can be the main overall cause of ignition (Johnson 1992). In countries around the Mediterranean basin as well as 
Author produced version of the article published in Environmental Management, 2013, 51, 3, 651-662

Original publication available at www.springer.com

doi:10.1007/s00267-012-9961-z

in other Mediterranean-type areas, where human-ignited fires dominate, lightning can trigger catastrophic events, even if it is not a common source of fire ignition. According to Vazquez and Moreno (1998), lightning-ignited fires are amongst the largest fires in Spain. In European boreal countries such as Sweden or Finland, natural fires are more frequent than in the Mediterranean region and in these countries, although vegetation and organic soil are important, the natural fire regime closely follows climate (Keranen 1929; Franssila 1959; Granström 1993; Larjaavara 2005). Indeed, in lightning-caused fires, fuel moisture content has a significant effect on ignition probability. Regarding the location of these types of fires, Alexandrian and Gouiran (1990) highlighted the fact that, in France, the ignition points tended to be within forests located in remote areas. In the Swiss Alps, fires caused by lightning also differed from fires of anthropogenic origin in their geographic distribution and duration (Conedera et al. 2006) and often occurred at higher elevations on steep relief; they were usually harder to extinguish because they led to ground fires. Even if the proportion of natural fires was lower than that of anthropogenic fires (26\% vs. $74 \%$ in the Canton Grison according to Langhart et al. 1998), it was higher in Switzerland than in other European countries, especially in the Mediterranean basin. Lightning caused 13\% of the total number of fires in Finland (Larjaavara et al. 2005a) and 8\% of the total number of fires in Sweden (Granström 1993) while it caused only 3.3\% of the total number of fires in Spain, according to Vazquez and Moreno (1998).

\section{Spatial distribution of fire occurrence}

Several studies emphasized the crucial role of human activity in the spatial distribution of wildfire ignitions (e.g. Catry et al. 2007). Analyses of spatial distributions carried out in Portugal showed that the least fire-prone areas were located along the coast, along most of the eastern border and especially in southern Portugal (Pereira et al. 1998). Most ignitions occur in the most populated municipalities and are intentional. Vazquez and Moreno (1998) showed that, in some parts of Spain, the spatial pattern of wildland fires caused by humans was less concentrated than lightning-caused fires; the highest fire ignition density of the latter appeared at the interface between wildlands and agricultural fields, especially between the northern edge of the Iberian Mountains and the southern edge of the Pyrenees. Unlike anthropogenic fires, which were distributed throughout the country, lightning-caused fires tended to be clustered in mountainous areas where they accounted for more than $50 \%$ of all fire occurrences. Furthermore, lightning-caused fire densities varied in the different geographical regions of Spain, ranging from 0.01 to 0.32 fires $/ 100 \mathrm{~km}^{2} /$ year.

Koutsias et al. (2002) found that the spatial arrangement of fire ignition points in the Grison region (Switzerland) was related to elevation. Human fire ignition thus tended to be located within the altitude ranges corresponding to the inhabited and cultivated sites whereas the spatial distribution pattern of lightning-ignited wildland fires mainly comprised mountainous regions. Fuel characteristics, such as moisture content, load, horizontal/vertical structure, are key elements explaining the spatial distribution of the lightning-caused fires.

The geographical variation in climate conditions can affect the spatial distribution of natural fire regimes in European boreal regions. According to Larjavaara (2005) and Larjavaara et al. (2005b), in Finland, the density of lightning-caused fires decreases significantly from south to north (from 0.1 to 0.01 fires/100 $\mathrm{km}^{2} /$ year). This north-south gradient could be explained by climate-caused variations in fuel moisture and lightning (Larjavaara et al. 2004; Tuomi 2002). The densities in Finland are similar to those reported at the same 
Author produced version of the article published in Environmental Management, 2013, 51, 3, 651-662

Original publication available at www.springer.com

doi:10.1007/s00267-012-9961-z

latitude in Sweden (0.23 to 0.05 fires $/ 100 \mathrm{~km}^{2} /$ year from southeast to north according to Granström 1993) and the two countries have a rather similar climate, vegetation and population density.

A significant correlation was observed between areas with a high density of human-caused fires and the level of landscape heterogeneity (Amatulli et al. 2007). These results agree with those of several studies carried out in the European Mediterranean region (Leone et al. 2003; Maselli et al. 1996; de la Riva and Perez-Cabello 2005; de la Riva et al. 2006) where the edges of rural-wildland interfaces were shown to be among the most susceptible areas to wildfires. In fact, fire susceptibility in this region is greatly affected by the level of landscape fragmentation and the so-called edge effect (Leone et al. 2003). A similar effect has been observed in tropical forests (Holdsworth and Uhl 1997; Cochrane and Schulze 1999; Cochrane and Laurence 2002).

\section{Temporal distribution of fire occurrence}

Fire occurrence displays typical temporal patterns that follow the natural cycles of environmental conditions and vegetation phenology, with temporal spans varying from one day to one year, with marked variations introduced when fire causes are taken into account. Where lightning-caused fires occur they tend to be concentrated in few days of the year, while anthropogenic fires are more evenly spread out in the year (Vazquez and Moreno 1998).

In France, Alexandrian and Gouiran (1990) showed that intentional fires were mostly ignited in summer, towards the end of the afternoon or in the evening, while fires due to agricultural or forestry operations occurred more frequently in autumn-winter and during the day. This has also been observed in countries where agricultural fires are still in use, and the temporal distribution of fires is clearly linked to this practice. For instance, in Germany, Bulgaria and Slovakia (Geiger 1948; Weck 1950; Missbach 1990; Bulgarian State Forestry Agency 2008; Tucek and Majlingova 2009), two peaks in fire occurrence were highlighted, the first in spring (March-April) and the second in summer, usually in August. Both peaks were mainly linked to farmers burning stubble. Generally, the highest fire occurrence was during the summer season and was linked to drought.

In the Grison area (Switzerland), the main fire season for human-caused fires is early spring (March and April) with most fires starting during the weekend due to negligence, $83 \%$ of the fires occurring between $10 \mathrm{am}$ and 6 pm (Langhart et al. 1998) and a second peak in the afternoon between 2 pm and 4 pm (Koutsias et al. 2002). Conversely, in Greece (Halkidiki Island), higher frequencies for both anthropogenic and natural fires were observed only during the summer (from July to September) between midday and 2 pm (Koutsias et al. 2002).

Regarding natural fire occurrence, in Switzerland and Finland, several studies showed that lightningcaused fires occur from May to October with a peak in July-August, and in Switzerland, up to 52\% of the fires occur between 4 pm and 8 pm (Conedera et al. 2006; Langhart et al. 1998; Koutsias et al. 2002; Tuomi 2004; Larjavaara 2005). During these two months, 91\% of the total fires were lightning-caused (Conedera et al. 2006). This result is in agreement with the work of Vazquez and Moreno (1998) who reported that $92 \%$ of the lightning-caused fires in Spain occurred during summer.

In the European Mediterranean countries results from the EFD show that from midday until midafternoon, fire causes are almost equally shared between voluntary and negligence/accidental (Figure 3), while voluntary fires are remarkably more frequent during the rest of the day and especially during the night. The peak 
Author produced version of the article published in Environmental Management, 2013, 51, 3, 651-662

Original publication available at www.springer.com

doi:10.1007/s00267-012-9961-z

of fire frequency during the day is at around 3 p.m. for human related causes, with a much more pronounced peak for accidental and negligence, while it is slightly postponed (5 pm.) for natural causes (Figure 4).

Concerning the frequency distribution along the year, voluntary fires are significantly more frequent during the summer months, while their frequency is closer to that of fires due to negligence during the remaining months (Figure 5). In June and July, natural fires represent almost 10\% of the total number of events (Figure 5). The frequency of natural and accidental fires clearly peaks in July, while the occurrence of voluntary and negligence fires has a maximum in August and a secondary peak in March (Figure 6).

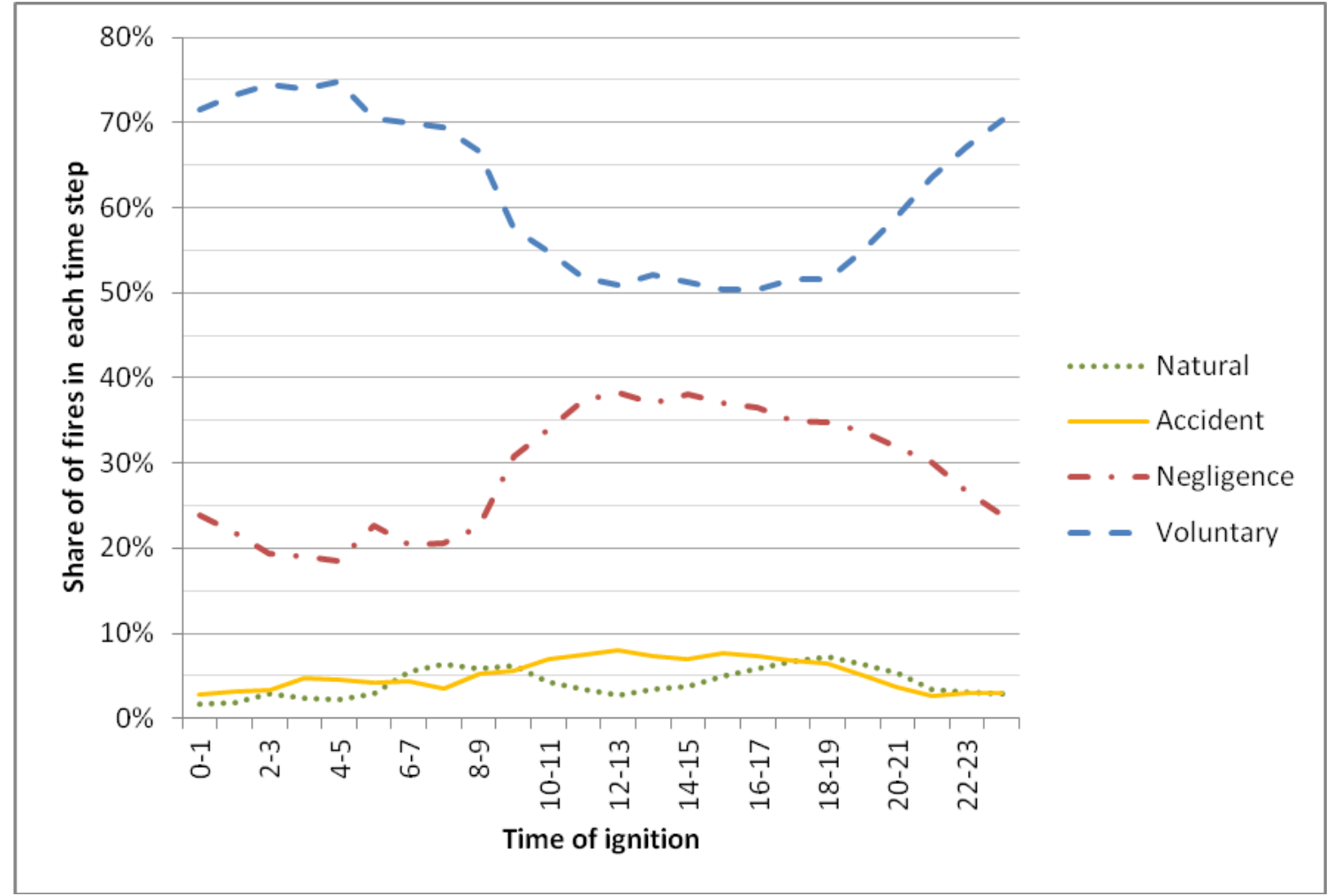

Fig. 3 Share of fire causes by hour of the day (EFD, Mediterranean countries, 2006-2010) 
Author produced version of the article published in Environmental Management, 2013, 51, 3, 651-662 Original publication available at www.springer.com

doi:10.1007/s00267-012-9961-z

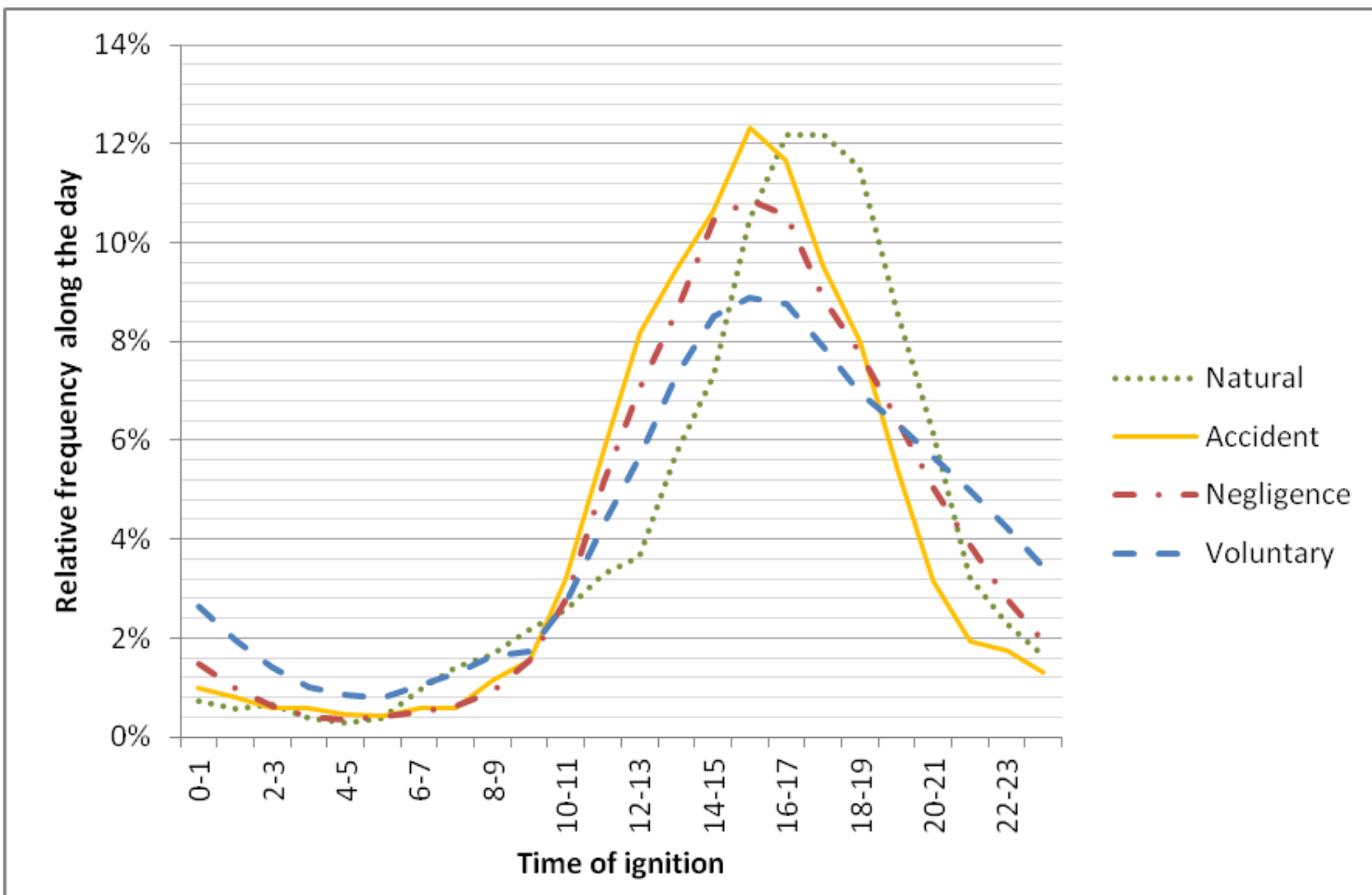

Fig. 4

Fire frequency along the day (frequency relative to total fires within each fire cause) in the Mediterranean countries (EFD 2006-2010)

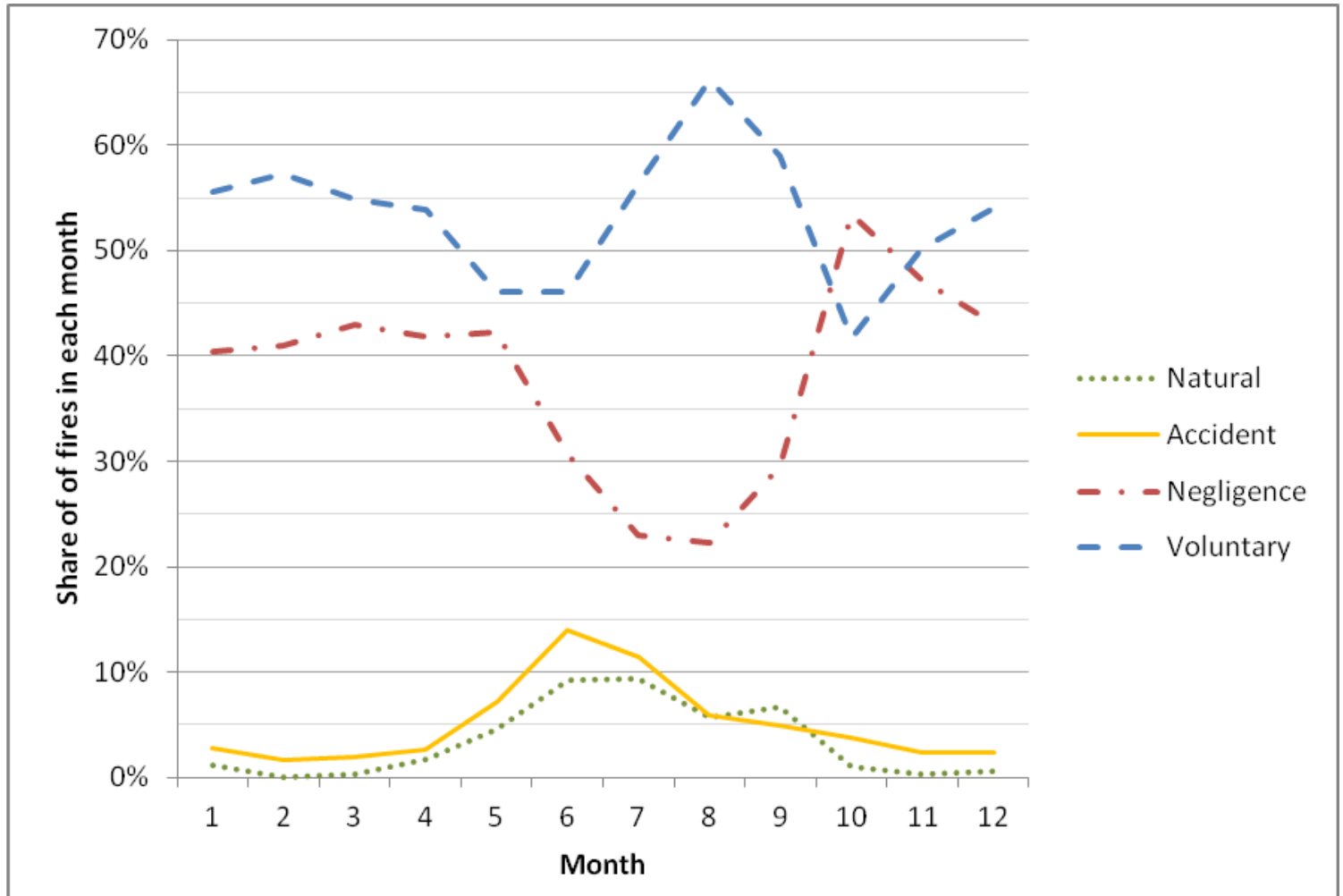

Fig. 5

Share of fire causes by month (EFD, Mediterranean countries, 2006-2010) 
Author produced version of the article published in Environmental Management, 2013, 51, 3, 651-662

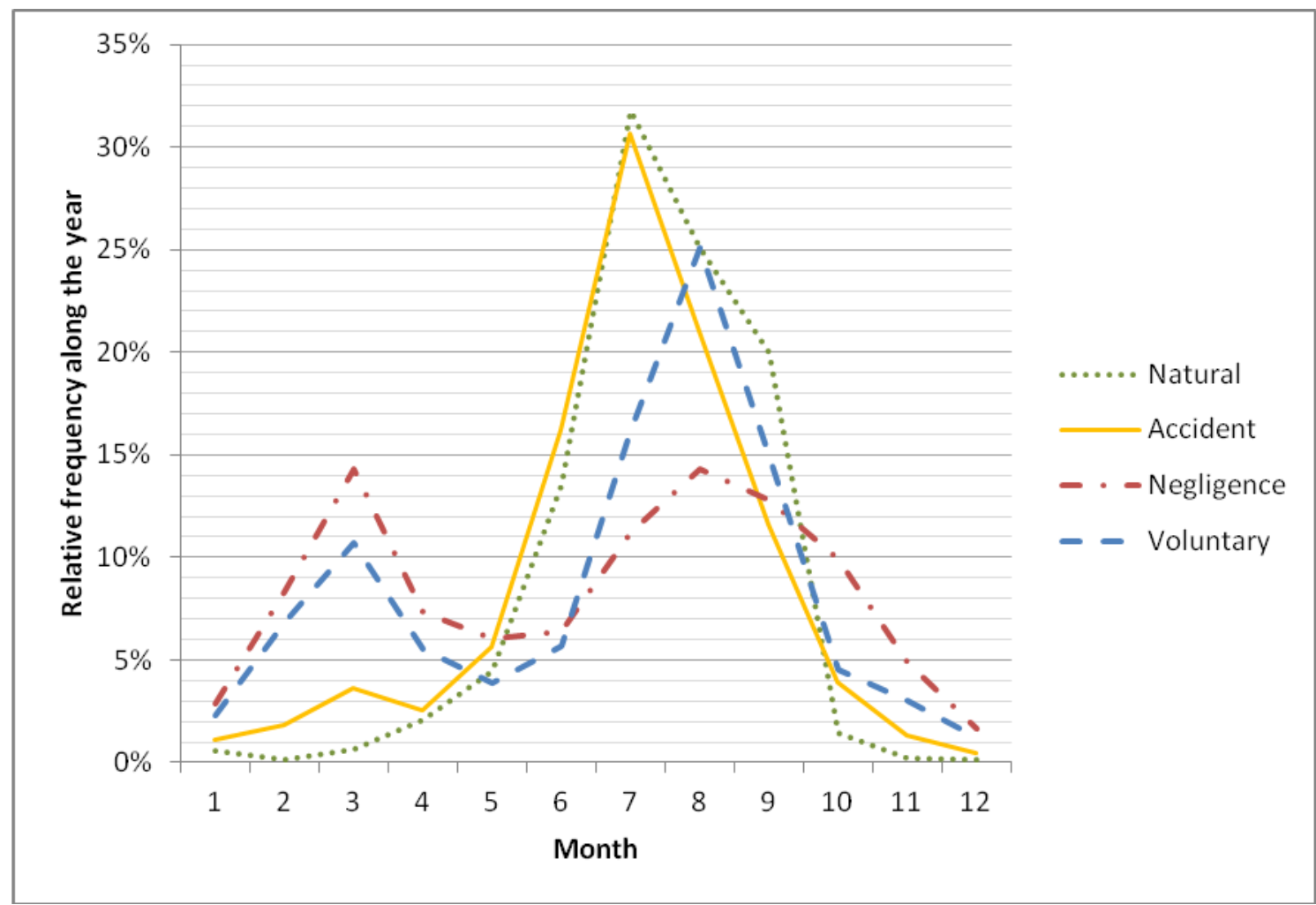

Fig. 6 Fire frequency in the months (frequency relative to total fires within each fire cause) in the Mediterranean countries (EFD 2006-2010)

\section{Comparison with countries outside Europe}

In densely populated Mediterranean regions such as California, the impact of anthropogenic pressure on fire regimes mirrors the expansion of the wildland-urban interface landscape and the increasing demand for recreation in wildland areas. A somewhat similar trend can be observed in many areas of southern Europe. Furthermore, like in Europe, fire occurrence is also highly impacted by natural factors such as land cover, ruggedness, etc. (Dickson et al. 2006). In the temperate rainforest on Vancouver Island (Canada), recreation and miscellaneous related fires tend to be significantly smaller than logging fires (Pew and Larsen 2001) and drivers of agricultural fires (mostly human-caused) differ from those of forest fires (Miranda et al. 2012). Overall, from the Canadian boreal forest to the mixed chaparral and conifer forest of southern California, fire ignitions are often spatially clustered and the probability of human-caused wildfires decreases with an increase in the distance from human infrastructures, where more fires occur at the wildland-urban interfaces than in the backcountry (Chou et al. 1993; Vega-García et al. 1993; Cardille et al. 2001; Zhai et al. 2003; Syphard et al. 2007a, b, 2008; Pew and Larsen 2001; Pyne 2001; Keeley et al. 2004; Yang et al. 2007; Bar Massada et al. 2009; Calef et al. 2009). However, in places where humans do not cause most fires, the probability of occurrence was greater in areas where road density was lower (Dickson et al. 2006). The same trend occurs in Russia, where the increasing exploitation of natural resources entails a high number of people per se, and an expanded road network that enables access to remote areas (Zakharov 1977; Noga and Tikhonov 1979; Sofronov and Vakurov 1981; Odintsov 1995; Sergienko 1996, 1999; Furyaev 1996; Karpachevskiy 2004; Achard et al. 2008); fire occurrence 
Author produced version of the article published in Environmental Management, 2013, 51, 3, 651-662

Original publication available at www.springer.com

doi:10.1007/s00267-012-9961-z

is thus driven only in part by environmental factors (Loboda 2009). Conversely, in other regions of the world, such as north-western Australia, fire frequency was found to be higher on pastoral lands and in areas located at a greater distance from roads (Vigilante et al. 2004).

Socio-economic factors such as the unemployment rate are increasingly taken into account when analysing fire causes in Mediterranean-type countries, as this factor has very often been linked with fire ignition. Indeed, several authors have pointed out that economic difficulties may promote conflicts that may result in the increase of intentional fires, which can be used as an instrument to force or maintain employment for seasonal workers (Bertrand and Baird 1975; Leone and Vita 1982; Ferreira de Almeida et al. 1992; Leone 1999; Velez 2000; Martínez et al 2009; Lovregio et al. 2010). In the USA, different situations occur and results differ between studies. Maingi and Henry (2007) found no relationship between fire occurrence and the county level unemployment rate whereas Prestemon and Butry (2005) showed that arson fires and economic factors such as poverty were related.

Syphard et al. (2008) found that, in the world's five Mediterranean climate ecosystems, the spatial relationship between human and fire was not linear, regardless of the land-cover type, the natural fire regime or the overall population. The presence of people strongly affected the frequency of fires. Both mean and median population densities were consistently and substantially higher in areas with fire when compared to areas without fires. This non-linear relationship was also underlined in the work of Miranda et al. (2012). These authors showed that most drivers underlying wildfire occurrence were dynamic but differed at spatial and temporal scales as it is the case for drought. Syphard et al. (2007) also found that human factors were increasingly overriding the biophysical influence in fire regimes.

As mentioned previously, in Europe, lightning-caused fires normally occur from May to October with a peak in July-August (Langhart et al. 1998; Koutsias et al. 2002; Conedera et al. 2006). This is also the case in Canada (Stocks et al. 2003), but with much higher frequency (48\% of fire causes by lightning in 2001-2010 ${ }^{1}$, as well as in the USA where natural fire occurrence is increasing during drought periods (Ruffner and Abrams 1998). In summer, the probability of ignition is positively correlated with summer temperature and negatively correlated with precipitation (Pew and Larsen 2001); additionally, there is a smaller peak in October caused by the senescence of the summer vegetation. However, in northern Canadian or American regions, lightning-caused fires burn a large share of the total burnt area in the countries because they are more likely to occur in remote areas where they are harder to detect and to reach; often, those fires in northern latitudes are left to burn undisturbed. According to Bryant (2008), in Australia, fires started by lightning can occur at any time of the day, but most natural fires coincide with the highest temperatures between midday and $6 \mathrm{pm}$, these being favourable to dry thunderstorm activity occurring during the bushfire danger period. During the normal season, this period is short but it can be extended due to more and more frequent El Niño events.

Temporal trends of fire occurrence depend on the scale of the study as drivers affecting occurrence are not the same at different scales. For instance, Miranda et al. (2012) showed that climate variables may not appear as important drivers because they operated on a scale that is broader than the regional scale; additionally, these authors found that the influence of socio-economic variables on fire regime was a function of the study scale, which reinforces the need for local information in the analysis of fire causality.

\footnotetext{
${ }^{1}$ Source : Canadian Forest Service, National Forestry Database, http://nfdp.ccfm.org/data/graph_31_a_e.php (verified $17^{\text {th }}$ September 2012)
} 
Author produced version of the article published in Environmental Management, 2013, 51, 3, 651-662

Original publication available at www.springer.com

doi:10.1007/s00267-012-9961-z

\section{Conclusions}

Good knowledge of the causes of forest fire, of the related motivations and of the spatial-temporal distribution of fires is crucial for the design of prevention policies adapted to the socio-economic, cultural and environmental circumstances of each region. Indeed, when their cause is known, fires are easier to eradicate and concrete actions can be taken to reduce their number. The causes of forest fires are many and their distribution differs among countries, additionally, fire causes may also differ spatially and temporally within the same country. In Europe, almost all fires are human-caused and in the European Mediterranean region, most of them are caused deliberately. This trend has begun to change showing an increase of the fires due to negligence with the current land use-land cover change.

Depending on the socio-economic context of the region concerned, factors such as the unemployment rate or variables linked to agricultural activity can explain the ignition of intentional and unintentional fires. Abiotic factors related to weather, fuel and topography are the most significant environmental factors that drive ignition of forest fires, especially in Mediterranean-type regions, but natural fires are clearly climate-driven. For both human and lightning-caused fires, there is a geographical gradient of fire ignition which is due to variations in climate and fuel composition but also to population density or elevation. However, lightning fires are found to be more clustered in specific areas (mountains, boreal regions). Landscape heterogeneity is also responsible for spatial variation in fire ignitions, but to a lesser extent. The timing of fires depends on their causes, fires due to arson occurring all over the day and being more frequent in summer than fires due to negligence or accident. In populated areas, the timing of human-caused fires is closely linked to human activities and peaks in the afternoon whereas, in remote areas, the timing of lightning-caused fires is more linked to weather conditions and the season, with most fires occurring in summer.

The main ignition factors and the spatial-temporal distribution of fire occurrence observed in Europe often mirror those underlined in other regions of the world such as USA, Canada or Australia; however, the fire frequency according to the cause can vary. A better understanding of the variation of the fire occurrence distribution throughout Europe will enable improved fire risk rating as well as fire prevention planning.

\section{Acknowledgments}

This work was funded by the Joint Research Centre of the European Commission, Service Contract n 384340

"Determination of forest fire causes and harmonization of methods for reporting them".

\section{References}

Achard F, Eva HD, Mollicone D, Beuchle R (2008) The effect of climate anomalies and human ignition factor on wildfires in Russian boreal forests. Philosophical Transactions of the Royal Society B-Biological Sciences 363: 2331-2339.

Alexandrian D (1995) Livre blanc “Routes et incendies” - Le cas du département des Bouches-du-Rhône, CETE Méditerranée.

Alexandrian D, Gouiran M (1990) Les incendies de forêts en France. Revue Forestière Française XLII. N special: 34-41. 
Author produced version of the article published in Environmental Management, 2013, 51, 3, 651-662

Original publication available at www.springer.com

doi:10.1007/s00267-012-9961-z

Altobellis AT (1983) A survey of rural population density and forest fire occurrence in the South, 1956-1970: USDA Forest Service, Southern Forest Experiment Station, Research Note SO-294, New Orleans.

Amatulli G, Perez-Cabello F, de la Riva J (2007) Mapping lightning/human-caused wildfires occurrence under ignition point location uncertainty. Ecological modelling 20: 321-333.

Archibald S, Roy DP, van Wilgen BW, Scholes RJ (2009) What limits fire? An examination of drivers of burnt area in Southern Africa. Global Change Biology 15: 613-630.

Badia-Perpinyà A, Pallares-Barbera M (2006) Spatial distribution of ignitions in Mediterranean peri-urban and rural areas: the case of Catalonia. International Journal of Wildland Fire 15: 187-196.

Bar Massada A, Radeloff VC, Stewart SI, Hawbaker TJ (2009) Wildfire risk in the wildland-urban interface: A simulation study in northwestern Wisconsin. Forest Ecology and Management 258: 1990-1999.

Bertrand AL, Baird AW (1975) Incendiarims in Southern Forest: A Decade of Sociological Research. In: USDA Forest Service (Ed.), Southern Forest Experiment Station Bulletin No. 838. Social Science Research Center at Mississippi University.

Bonora L, Conese C, Lampin C, Martin P, Martínez J, Molina D, Salas J (2002) Towards methods for investigating on wildland fire causes. Euro-Mediterranean Wildland Fire Laboratory, a "wall-less" Laboratory for Wildland Fire Sciences and Technologies in the Euro-Mediterranean Region. Deliverable D05-02.

Bossard M, Feranec J, Otahel J (2000) Corine land cover technical guide. Addendum 2000. Copenhagen, EEA.

Brown TJ, Hall BL, Mohrle CR, Reinbold HJ (2002) Coarse assessment of federal wildland fire occurrence data. Report for the National Wildland Fire Coordinating Group, CEFA Report 02-04.

Bryant C (2008) Understanding bushfire: trends in deliberate vegetation fires in Australia. Technical and background paper series 27, Australian Institute of Criminology, Canberra.

Bulgarian State Forestry Agency (2008) Bulgarian Fire Report.

Calef M, McGuire A, Chapin III F (2009) Human influences on wildfire in Alaska from 1988 through 2005: an analysis of the spatial patterns of human impacts. Earth Interactions, 12, Paper 1.

Camia A, Durrant Houston T, San-Miguel J (2010) The European Fire Database: Development, Structure and Implementation In: Viegas D.X. (Ed.), Proc. VI International Conference on Forest Fire Research. Coimbra.

Cardille JA, Ventura SJ, Turner MG (2001) Environmental and social factors influencing wildfires in the upper Midwest, United States. Ecological Applications 11: 111-127.

Carmona-Moreno C, Belward A, Malingreau JP, Hartley A, García-Alegre M, Antonovskiy M, Buchshtaber V, Pivoravov V (2005) Characterizing interannual variations in global fire calendar using data from Earth observing satellites, Global Change Biol. 11: 1537-1555.

Catry FX, Damasceno P, Silva JS, Galante M, Moreira F (2007) Spatial Distribution Patterns of Wildfire Ignitions in Portugal. Conference Wildfire 2007, Seville (Spain).

Chou Y, Minnich R, Chase R (1993) Mapping probability of fire occurrence in San Jacinto Mountains, California, USA. Environmental Management 17: 129-140.

Chuvieco E, Congalton RG (1989) Application of remote sensing and Geographic Information Systems to Forest fire hazard mapping. Remote Sensing of Environment 29: 147-159. 
Author produced version of the article published in Environmental Management, 2013, 51, 3, 651-662

Original publication available at www.springer.com

doi:10.1007/s00267-012-9961-z

Chuvieco E, Justice C (2010) Relations between Human Factors and Global Fire Activity. In E Chuvieco, J Li \& X Yang (Eds.), Advances in earth observation of global change (pp. 187-200). Dordrecht ; London: Springer.

Chuvieco E, Salas FJ, Carvacho L, Rodríguez-Silva F (1999) Integrated fire risk mapping. In: Chuvieco E (ed) Remote Sensing of Large Wildfires in the European Mediterranean Basin, Berlin Springer-Verlag, pp 61-84.

Chuvieco E, Aguado I, Yebra M, Nieto H, Salas J, Martín MP, Vilar L, Martínez J, Martín S, Ibarra P, de la Riva

J, Baeza J, Rodríguez F, Molina JR, Herrera MA, Zamora R (2010) Development of a framework for fire risk assessment using remote sensing and geographic information system technologies. Ecological Modelling 221: 46-58. doi:10.1016/ J.ECOLMODEL.2008.11.017.

Cochrane MA, Schulze MD (1999) Fire as a recurrent event in tropical forests of eastern Amazon: effects on forest structure, biomass and species composition. Biotropica 31: 2-16.

Cochrane MA, Laureance WF (2002) Fire as a large-scale edge effect in Amazonian forests. Journal of Tropical Ecology 18: 311-325.

Conedera M, Cesti G, Pezzatti GB, Zumbrunnen T, Spinedi F (2006) Lightning-induced fires in the Alpine region: An increasing problem. V International Conference on Forest Fire Research, Portugal.

Cunningham AA, Martell DL (1976) The use of subjective probability assessments to predict forest fire occurrence. Canadian Journal of Forest Research 6: 348-356.

Decarnin E, 2002. Etude du risque incendie. Mise en place d’une méthodologie pour la création d'un indice de risque anthropique d’éclosion de feux de forêt. Mémoire de DEA. Structures et Dynamiques Spatiales, Université de Provence.

De la Riva J, Perez-Cabello F (2005) El factor humano en el riesgo de incendios forestales a escala municipal. Aplicación de técnicas SIG para su modelización. In La ciencia forestal: respuestas para la sostenibilidad. 4。 Congreso Forestal Español. Sociedad Española de Ciencias Forestales, Madrid.

De la Riva J, Perez-Cabello F, Chuvieco E (2006) Wildland fire ignition danger spatial modelling using GIS and satellite data. In: EGU General Assembly_European Geosciences Union. Geophysical Research Abstracts 8, pp 10321.

Dickson BG, Prather JW, Xu Y,. Hampton HM, Aumack EN, Sisk TD (2006) Mapping the probability of large fire occurrence in northern Arizona, USA. Landsc. Ecol. 2: 747-761.

Donoghue LR, Main WA (1985) Some Factors Influencing Wildfire Occurrence and Measurement of Fire Prevention Effectiveness. Journal of Environmental Management 20 (1): 87-96.

Duguy B (1998) Reconstruccion de los cambios en los usos del suelo y en la estructura del paisaje (1956-1994). Interaccion con los incendios. Caso de una zona piloto en la provincia de Alicante. Ph.D. Thesis. Centro Internacional de Altos Estudios Agronomicos Mediterráneos, Instituto Agronomico Mediterraneo de Zaragoza, Zaragoza, Spain.

FAO (1986) Wildland Fire Management Terminology. FAO Forestry Paper 70, Food and Agriculture Organization of the United Nations, Rome.

FAO (2007) Fire management - global assessment 2006. FAO Forestry Paper 151. Rome.156 p.

Farina A (1998) Principles and Methods in Landscape Ecology. Chapman and Hall Ltd, Cambridge, UK.

Ferreira de Almeida AMS, Vilacae-Moura PVS (1992) The relationship of forest fires to agro-forestry and socioeconomic parameters in Portugal. International Journal of Wildland Fire 2: 37-40. 
Author produced version of the article published in Environmental Management, 2013, 51, 3, 651-662

Original publication available at www.springer.com

doi:10.1007/s00267-012-9961-z

Follin JM (1999) Evaluation des risques naturels anthropiques d'éclosion de feux de forêt à l'Ets des Bouchesdu-Rhône. Mémoire de géographie. Université de Provence.

Franssila M (1959) Kulovaaran ja säätekijöiden välisestä riippuvuudesta (in Finnish, summary in English, ”The dependence of forest fire danger on meteorological factors”). Acta Forestalia Fennica 67.

Fuentes ER, Segura AM, Holmgren M (1994) Are the responses of matorral shrubs different from those in an ecosystem with reputed fire history? In: Moreno JM and Oechel WC (eds) The Role of Fire in Mediterranean-Type Ecosystems. Ecological Studies 107, Springer-Verlag, NewYork, pp 16-25.

Furyaev VV (1996) Rol pozharov v protsesse lesoobrazovaniya. [The Role of Fires in the Process of Forest Formation]. Novosibirsk, In Russian.

Geiger R (1948) Neue Unterlagen für eine Waldbrandbekämpfung 2.Teil. Witterungsbedingungen für Großwaldbrände. Mitteilungen des Reichsinstitutes für Forst- und Holzwirtschaft Nr. 5.

Gill AM, Groves RH, Noble IR (1981) Fire and the Australian Biota. Australian Academy of Science, Camberra, Australia.

Granström A (1993) Spatial and temporal variation in lightning ignitions in Sweden. Journal of Vegetation Science 4: 737-744.

Hardy C (2005) Wildland fire hazard and risk: problems, definitions,and context. Forest Ecology and Management 211: 73-82.

Henderson M, Kalabokidis K, Marmaras E, Konstantinidis P, Marangudakis M (2005) Fire and society: a comparative analysis of wildfire in Greece and the United States. Hum Ecol Rev 12(2): 169-182.

Hill J, Stellmes M, Udelhoven T, Röder A, Sommer S (2008) Mediterranean desertification and land degradation: Mapping related land use change syndromes based on satellite observations. Global and Planetary Change 64 : 146-157.

Holdsworth AR, Uhl C (1997) Fire in eastern Amazonian logged rain forest and potential for fire reduction. Ecological Applications 7: 713-725.

Johnson EA (1992) Fire and the vegetation dynamics: studies from the North American boreal forest. Cambridge Studies in Ecology, Cambridge University Press, Cambridge, UK.

JRC-IES (2008) Forest Fires in Europe. Report n ${ }^{\circ}$ 9/2009. JRC Scientific and Technic Reports. 88 p.

Karpachevskiy M (2004) Forest fires in the Russia taiga. Taïga Rescue Network: 8.

Keeley JE (1982) Distribution of lightning and man-caused wildfires in California. In: Conrad CE and Oechel WC (eds) Dynamics and Management of Mediterranean-Type Ecosystems. United States Department of Agriculture, Forest Service, PSW-58, pp 431-437.

Keeley JE, Keeley SC (1988) Chaparral. In: Barbour MG and Billings WD (eds) North American Terrestrial Vegetation. Cambridge University Press, New York, pp 165-207.

Keeley JE, Fotheringham CJ, Moritz MA (2004) Lessons from the 2003 wildfires in southern California. Journal of Forestry 102: 26-31

Keränen J (1929) Blitzschlag als Zünder der Waldbrande im nördlichen Finnland (in German). Acta Forestalia Fennica 34: .25.

Komarek EV (1964) The natural history of lightning. Third Annual Tall Timbers Fire Ecology Conference, Tallahassee, Florida, pp 139-183. 
Author produced version of the article published in Environmental Management, 2013, 51, 3, 651-662

Original publication available at www.springer.com

doi:10.1007/s00267-012-9961-z

Koutsias N, Allgöwer B, Conedera M (2002) What is common in wildland fire occurrence in Greece and Switzerland? - Statistics to study fire occurrence pattern. In: Viegas DX (ed.) Proceedings of the $4^{\text {th }}$ International Conference on Forest Fire Research, Luso, Portugal, November 18-23, Millpress Science Publishers Rotterdam, Netherlands, pp 14.

Koutsias N, Arianoutsou M, Kallimanis AS, Mallinis G, Halley JM, Dimopoulos P (2012) Where did the fires burn in Peloponnisos, Greece the summer of 2007? Evidence for a synergy of fuel and weather. Agricultural and Forest Meteorology 156: 41-53.

Kruger FJ, Bigalke RC (1984) Fire in Fynbos. In:. Booysen PdeV and Tainton NM (eds) Ecological Effects of Fire in South African Ecosystems. Ecological Studies 48,Springer-Verlag, pp 67-114.

Lampin C, Jappiot M, Morge D, Borgniet L (2005) Amélioration de la connaissance de l'origine des feux de forêt dans les 15 départements du Sud-Est. DPFM 2003/252 - Proposition nº3-08-22 du 22 août 2003.

Lampin C, Jappiot M, Morge D, Vennetier M (2006) Statistical and spatial analysis of forest fire ignition points: a study case in South of France. Forest Ecology and Management 234S-S12.

Langhart R, Bachmann A, Allgöwer B (1998) Spatial and Temporal Patterns of Fire Occurrence (Canton of Grison, Switzerland). In: Viegas DX (ed) Proceedings of the 3rd International Conference on Forest Fire Research / 14th Conference on Fire and Forest Meteorology, Luso, Portugal, November, 16-20, Vol.2, pp 2279-2292.

Larjavaara M (2005) Climate and forest Fires in Finland - influence of lightning-caused ignitions and fuel moisture. Dissertationes Forestales 5. Yliopistopaino, Helsinki.

Larjavaara M, Kuuluvainen T, Tanskanen H, Venäläinen A (2004) Variation in Forest Fire Ignition Probability in Finland. Silva Fenn 38 (3): 253-266.

Larjavaara M, Pennanen J, Tuomi TJ (2005a) Lightning that ignites forest fires in Finland. Agricultural and Forest Meteorology 132: 171-180.

Larjavaara M, Kuuluvainen T, Rita H (2005b) Spatial distribution of lightning-ignited forest fires in Finland. Forest Ecology and Management 208: 177-188.

Lazaro A, Montiel C (2010). Overview of prescribed burning policies and practices in Europe and other countries. In: Sarde-Silva J, Rego F, Fernandes P and Rigolot E (eds) Towards integrated fire managementOutcomes of the European project Fire Paradox, European Forest Institute Research Report 23: pp 137-150.

Lekakis JN (1995) Social and Ecological Correlates of Rural Fires in Greece. Journal of Environmental Management 43: 41-47.

Leone V (1999) Los incendios en el Mediodia Italiano. In: Araque Jimenez E (ed) Incendioshistoricos: una aproximacion multidisciplinar. Universidad Internacional de Andalucia, Seville.

Leone V, Vita F ( 1982) Incendi boschivi e marginalitá economica: il caso della. Puglia Cellulosa e Carta 7/8: 41-57.

Leone V, Koutsias N, Martínez J, Vega-García C, Allgöwer B, Lovreglio R (2003) The human factor in fire danger assessment. In: Chuvieco E (ed.), Wildland Fire Danger Estimation and Mapping: The Role of Remote Sensing Data, World Sci., Hackensack, N.J., pp 143-196.

Le Page Y, Oom D, Silva J, Jönsson P, Pereira J (2010). Seasonality of vegetation fires as modified by human action: observing the deviation from eco climatic fire regimes. Global Ecology and Biogeography 19: 575588. 
Author produced version of the article published in Environmental Management, 2013, 51, 3, 651-662

Original publication available at www.springer.com

doi:10.1007/s00267-012-9961-z

Loboda TV (2009) Modeling fire danger in data-poor regions: a case study from the Russian Far East. International Journal of Wildland Fire 18: 19-35.

Lovreglio R, Leone V, Giaquinto P, Notarnicola A (2006) New tools for the analysis of fire causes and their motivations: the Delphi technique. Forest Ecology and Management 234 (1): 18-33.

Lovreglio R, Leone V, Giaquinto P, Notarnicola A (2010) Wildfire cause analysis: four case-studies in southern Italy. iForest 3: 8-15.

Maingi J.K, Henry MC (2007) Factor influencing wildfire occurrence and distribution in eastern Kentucky, USA. International Journal of Wildland Fire 16: 23-33.

Mangiavillano A (2004) De l'éclosion du phénomène à l'émergence d'incendie : utilisation combine de l'analyse spatiale et de la physique du feu pour localiser les espaces émetteurs. Mémoire de DEA de Géographie, Université d'Avignon.

Martínez J, Vega-García C, Chuvieco E (2009) Human-caused wildfire risk rating for prevention planning in Spain. Journal of Environmental Management 90: 1241-1252.

Maselli R, Botai L, Conese C (1996) Evaluation of forest fire risk by the analysis of environmental data and TM images. International Journal of Remote Sensing 17 (7): 1417-1423.

Miranda BR, Sturtevant BR, Stewart SI, Hammer RB (2012) Spatial and temporal drivers of wildfire occurrence in the context of rural development in northern Wisconsin, USA. International Journal of Wildland Fire 21: $141-154$.

Missbach K (1990) Zur Auswertung der Waldbrandstatistik der DDR. Forstwirtschaft Berlin 40: 3.

Mollicone D, Eva HD, Achard F (2006) Human role in Russian wildfires. Nature 440: 436-437.

Moreira F, Rego FC, Ferreira PG (2001) Temporal (1958-1995) pattern of change in a cultural landscape of northwestern Portugal: implications for fire occurrence. Landscape Ecology 16: 557-567.

Moreira F, Vaz P, Catry F, Silva JS (2009) Regional variations in wildfire susceptibility of land-cover types in Portugal: implications for landscape management to minimize fire hazard. International Journal of Wildland Fire 18: 563-574.

Moreira F, Viedma O, Arianoutsou M. Curt T, Koutsias N, Rigolot F, Barbati A, Corona P, Vaz P, Xanthopoulos G, Mouillot F, Bilgili E (2011) Landscape-wildfire interactions in southern Europe: Implications for landscape management. Jouranl of Environmental Management 92: 2389-2402.

Naveh Z (1975) The evolutionary significance of fire in the Mediterranean region. Vegetatio 9: 199-206.

Noga LG, Tikhonov VV (1979) O vozniknovenii lesnykh pozharov ot groz. [On the occurrence of forest fires from lightning.] Lesnoe khozyaistvo 6: 58-59. In Russian.

NWCG (2006) Glossary of Wildland Fire Terminology. National Wildfire Coordinating Group, PMS 205, Boise, Idaho.

Odintsov DI (199) Okhrana lesov ot ognya - zadacha obshchaya. [Forest protection against fire as a common task.] Lesnoe khozyaistvo 2: 28-31. In Russian.

Padilla M, Vega-García C (2011). On the comparative importance of fire danger rating indices and their integration with spatial and temporal variables for predicting daily human-caused fire occurrences in Spain. International Journal of Wildland Fire 20: 46-58.

Pereira JMC, Carreiras JMB, De Vasconcelos PMJ (1998) Exploratory data analysis of the spatial distribution of wildfires in Portugal, 1980-1989. Geographical Systems 5 (4): 355-390. 
Author produced version of the article published in Environmental Management, 2013, 51, 3, 651-662

Original publication available at www.springer.com

doi:10.1007/s00267-012-9961-z

Pew KL, Larsen CPS (2001) GIS analysis of spatial and temporal patterns of human-caused wildfires in the temperate rainforest of Vancouver Island, Canada. Forest Ecology and Management 140: 1-18.

Prestemon JP, Butry DT (2005) Time to burn: modeling wildland arson as an autoregressive crime function. American Journal of Agricultural Economics 87: 756-770.

Pyne SJ (2001) Fire in America. Princeton University Press. Princeton, New Jersey, USA.

Richardson DM, van Wilgen BW (1992) Ecosystem, community and species response to fire in mountain Fymbos: Conclusions from Swartboskloof experiment. In: van Wilgen BW, Richardson DM, Kruger FJ and van Hensbergen HJ (eds) Fire in South African Mountain Fynbos.Ecological Studies 93, Springer-Verlag, Berlin, pp 273-284.

Ricotta C, Guglietta D, Migliozzi A (2012) No evidence of increased fire risk due to agricultural land abandonment in Sardinia (Italy). Natural Hazards and Earth System Sciences 12: 1333-1336. doi:10.5194/nhess-12-1333-2012.

Romero-Calcerrada R, Perry GLW (2004) The role of land abandonment in landscape dynamics in the SPA 'Encinares del río Alberche y Cofio, Central Spain, 1984-1999. Landsc Urban Plan 66:217-232.

Romero-Calcerrada R, Novillo J, Millington JDA, Gomez-Jimenez I (2008) GIS analysis of spatial patterns of human-caused wildfire ignition risk in the SW of Madrid (Central Spain). Landscape Ecology 23: 341-354.

Ruffner CM, Abrams MD (1998) Lightning strikes and resultant fires from archival (1912-1917) and current (1960-1997) information in Pennsylvania. The Journal of the Torrey Botanical Society 125: 249-252. doi:10.2307/2997223

Russell-Smith J, Ryan PG, Durieu R (1997) A LANDSAT MSS-derived fire history of Kakadu National Park, monsoonal northern Australia, 1980-94: seasonal extent, frequency and patchiness. Journal of Applied Ecology 34: 748-766.

San-Miguel-Ayanz J, Camia A (2010) Forest Fires. In: Mapping the impacts of natural hazards and technological accidents in Europe: an overview of the last decade. EEA Technical report No 13/2010, Publications Office of the European Union, Luxembourg, pp 49-55.

San-Miguel-Ayanz J, Schulte E, Schmuck G, Camia A, Strobl P, Liberta G, Giovando C, Boca R, Sedano F, Kempeneers P, McInerney D, Withmore C, Santos de Oliveira S, Rodrigues M, Durrant T, Corti P, Oehler F, Vilar L, Amatulli G, (2012) Comprehensive monitoring of wildfires in Europe: The European Forest Fire Information System (EFFIS). In: Tiefenbacher J (Ed), Approaches to Managing Disaster - Assessing Hazards, Emergencies and Disaster Impacts, InTech, DOI: 10.5772/1112.

Santos De Oliveira S, Camia A, San-Miguel-Ayanz J (2009) First Steps towards a Long Term Forest Fire Risk of Europe. In: Chuvieco E and Lasaponara R (eds) Proceedings of the VII International EARSeL Workshop - Advances on Remote Sensing and GIS applications in Forest Fire Management. Potenza (Italy), Il Segno. pp 79-83.

Sebastián-López A, Salvador-Civil R, Gonzalo-Jimenez J, San-Miguel-Ayanz J (2008) Integration of socioeconomic and environmental variables for modelling long-term fire danger in Southern Europe. European Journal of Forest Research 127: 149-163

Sergienko VN (1996) Sokhranim li nashi lesa? [Will we be able to preserve our forest?] Lesnoe khozyaistvo 3: 5-6. In Russian. 
Author produced version of the article published in Environmental Management, 2013, 51, 3, 651-662

Original publication available at www.springer.com

doi:10.1007/s00267-012-9961-z

Sergienko V.N., 19 Sergienko VN (1999) Borba s lesnymi pozharami: problemy I zadachi. [Fight against forest fires: problems and tasks.] Lesnoe khozyaistvo 4: 47-51. In Russian.

Shlisky A, Waugh J, Gonzalez P, Gonzalez M, Manta M, Santoso H, Alvarado E, Ainuddin Nuruddin A, Rodríguez-Trejo DA, Swaty R, Schmidt D, Kaufmann M, Myers R, Alencar A, Kearns F, Johnson D, Smith J, Zollner D, Fulks W (2007) Fire, Ecosystems and People: Threats and Strategies for Global Biodiversity Conservation. Arlington, VA: The Nature Conservancy.

Sofronov MA, Vakurov AD (1981) Ogon v lesu. [Fire in the forest.] Novosibirsk: Nauka. In Russian.

South Australia Country Fire Service. 2007-2008 Annual report.

Stocks BJ, Mason JA, Todd JB, Bosch EM, Wotton BM (2003) Large forest fires in Canada, 1959-1997. Journal of Geophysical Research 108: FFR5-1-FFR5-12.

Sturtevand BR, Cleland DT (2007) Human and biophisical factors influencing modern fire disturbance in northern Wisconsin. International Journal of Wildland Fire 16: 398-413.

Syphard AD, Clarke KC, Franklin J (2007a) Simulating fire frequency and urban growth in southern California coastal shrublands, USA. Landscape Ecology 22: 431-445.

Syphard AD, Radeloff VC, Keeley JE, Hawbaker TJ, Clayton MK, Stewart SI, Hammer RB (2007b) Human influence on California fire regimes. Ecological Applications 17(5): 1388-1402.

Syphard AD, Radeloff VC, Keuler NS, Taylor RS, Hawbaker TJ, Stewart SI, Clayton MK (2008) Predicting spatial patterns of fire on a southern California landscape. International Journal of Wildland Fire 17: 602613.

Tabara D, Sauri D, Cerdan R (2003) Forest fire risk management and public participation in changing socioenvironmental conditions: A case study in a Mediterranean region. Risk Analysis 23: 249-260.

Thompson MP, Calkin DE, Finney MA, Ager AA, Gilbertson-Day JW (2011) Integrated national-scale assessment of wildfire risk to human and ecological values. Stochastic Environmental Research and Risk Assessment, DOI 10.1007/s00477-011-0461-0.

Tuček J, Majlingová A (2009) Forest fire vulnerability analysis, 219-230. In: Strelcova K et al. (eds) Bioclimatology and natural hazards, DOI 10.1007/978-8876-6-19, (C) Springer Science+Business Media B.V.

Tuomi TJ (2002) Lightning observations in Finland, FinnishMeteorological Institute, Helsinki.

Tuomi TJ (2004) Lightning observations in Finland. Finnish Meteorological Institute, Helsinki.

Vannière B, Colombaroli D, Chapron E, Leroux A, Tinner W, Magny M (2008) Climate versus human-driven fire regimes in Mediterranean landscapes: the Holocene record of Lago dell'Accesa (Tuscany, Italy). Quaternary Science Reviews 27: 1181-1196.

Vasconcelos de MJP, Silva S, Tomé M, Alvim M, Pereira JMC (2001) Spatial prediction of fire ignition probabilities: comparing logistic regression and neural networks. Photogrammetric Engineering and Remote Sensing 67 (1): 73-83.

Vasilakos C, Kalabokidis K, Hatzopoulos J, Kallos G, Matsinos J (2007) Integrating new methods and tools in fire danger rating. International Journal of Wildland Fire 16 (3): 306-316.

Vasilakos C, Kalabokidis K, Hatzopoulos J, Matsinos J (2008) Identifying wildland fire ignition factors through sensitivity analysis of a neural network. Natural hazards: 1-19. 
Vazquez A, Moreno JM (1993) Sensitivity of fire occurrence to meteorological variables in Mediterranean and Atlantic areas of Spain. Landscape and urban Planning 24: 129-142.

Vazquez A, Moreno JM (1998) Patterns of Lightning-, and People-Caused Fires in Peninsular Spain. International Journal of Wildland Fire 812: 103-115.

Vazquez A, Moreno JM (2001) Spatial distribution of forest fires in Sierra de Gredos (Central Spain). Forest Ecology and Management 147: 55-65.

Vega-García C, Woodard P, Lee B (1993) Geographic and temporal factors that seem to explain human-caused fire occurrence in Whitecourt Forest, Alberta. In: Proceedings of Symposium on GIS'93 International. Vancouver, Canada, 1, pp 115-119.

Vega-García C, Woodard T, Adamowicz WL, Lee B (1995) A logit model for predicting the daily occurrence of human caused forest fires. International Journal of Wildland Fire 5 (2): 101-111.

Velez R (2000) La prevencion. In: García-Brage A (ed) La defensa contra incendios forestales fundamentos y experiencias. McGraw-Hill/Interamericana de Espana, Madrid.

Vigilante T, Bowman DMJS, Fisher R, Russell-Smith J, Yates C (2004) Contemporary landscape burning patterns in the far North Kimberley region of north-west Australia: human influences and environmental determinants. Journal of Biogeography 31: 1317-1333.

Weck J (1950) Waldbrand, seine Vorbeugung und Bekämpfung. Brandschutz-Fachbuchreihe 19, W. Kohlhammer Verlag.

Yang J, He HS, Shifley SR, Gustafson EJ (2007) Spatial patterns of modern period human-caused fire occurrence in the Missouri Ozark Highlands. Forest Science 53: 1-15.

Zakharov AN, Stolyrchuk AV (1977) Pozhary ot groz v lesakh Tyumenskoy oblasti. [Fires caused by thunderstorms in forest of Tyumen Oblast.] Lesnoe khozyaistvo 7: 74-75. In Russian.

Zhai Y, Munn IA, Evans DL (2003) Modeling forest fire probabilities in the south central United States using FIA data. Southern Journal of Applied Forestry 27: 11-17. 